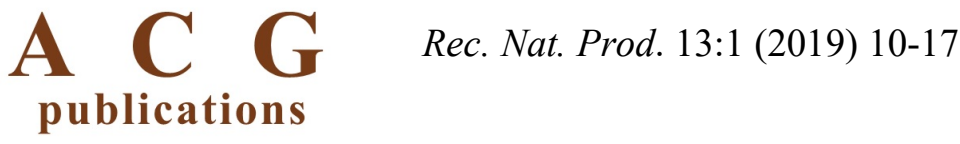

records of natural products

\title{
Antinociceptive Activity of Essential Oils from Wild Growing and Micropropagated Plants of Renealmia alpinia (Rottb.) Maas
}

\author{
Isabel Gómez-Betancur ${ }^{\oplus 1^{*}}$, Dora Benjumea ${ }^{\oplus 1}$, Juan E. Gómez ${ }^{\oplus 1}$, \\ Natalia Mejía $^{\oplus 1}$ and Juan F. León ${ }^{\oplus 2}$ \\ ${ }^{1}$ Programa Ofidismo-Escorpionismo, Facultad de Ciencias Farmacéuticas y Alimentarias, \\ Universidad de Antioquia, Medellín 1226, Colombia \\ ${ }^{2}$ Department of Medicinal Chemistry, College of Pharmacy, University of Florida, Gainesville, \\ Florida, 32610, United States
}

(Received January 26, 2018; Revised April 11, 2018; Accepted April 12, 2018)

\begin{abstract}
Renealmia alpinia is a medicinal plant that has been cultivated and used for the treatment of headaches, abdominal pain, as a febrifuge and to treat snake bites in southeast Colombia and in the Caribbean islands. Moreover, its edible fruits are commonly used as spice in Mexico. The $R$. alpinia leave-extracts have shown enzymatic inhibition of Bothrops atrox and Bothrops asper snake poison. The extracts also showed effects as a peripheral analgesic agent. This report investigates the analgesic activity of the essential oils obtained by hydrodistillation from wild and in vitro propagation samples of $R$. alpinia as well as the chemical profile using GC-MS. The essential oils isolated from $R$. alpinia evaluated on concentrations of $50,75 \mathrm{and} 100 \mathrm{mg} / \mathrm{kg}$ showed significant antinociceptive effects in the test of acetic-acid-induced abdominal writhing, compared to the control animals. The essential oil of the wild flora leaves showed the highest percentage of pain inhibition by $200 \mathrm{mg} / \mathrm{kg}$, concluding that the essential oil of $R$. alpinia presents antinociceptive activity in an in vivo model. These results help us to understand the traditional use of $R$. alpinia to treat pain and make it a potential source for the development of phytopharmaceutics.
\end{abstract}

Keywords: Renealmia alpinia; essential oil; antinociceptive; micropropagation . C 2018 ACG Publications. All rights reserved.

\section{Introduction}

Pain is one of the health problems that most affects the quality of people's lives, which produces a significant economic and social burden [1]. According to the Colombian Association for the study of Pain, $70 \%$ of the Colombian population has suffered some sort of pain during the last six months (acute and chronic), 47\% for chronic pain (64.5\% of musculoskeletal type - in lower limbs and back, $23 \%$ of craniofacial type, and $7.8 \%$ of abdominal pain) and between severe and moderate intensity (41.0\% and 39.0\%, respectively) [2]. Phytotherapy is an important alternative for the treatment of pain because it is accessible to wide range of the population, covering the needs of primary care in health $[3,4]$ in developing countries and also in developed countries such as Italy,

\footnotetext{
* Corresponding author E- Mail: isabel.gomezbetancur@yahoo.com ; Phone: +57 3187509914
} 
Germany and France, as an alternative or complementary therapy $[3,5]$. The motivations for the use of medicinal plants as therapy for the treatment of pain result from disappointment with conventional therapies, due in many cases to their lack of effectiveness, as well as fear of the adverse/side effects of the drugs especially non-steroidal anti-inflammatory drugs (NSAIDs) [6,7].

Some extracts and essential oils from plants of the Zingiberaceae family have shown to be active in the treatment of pain [8-10]. This is particularly prevalent in southeast Colombia where indigenous natives use $R$. alpinia in the treatment of bites by poisonous snakes [11]. This plant has also been used in other countries in the Americas for the treatment of headache [12] and stomach pain [13], among others maladies. Moreover, the fruits and leaves of $R$. alpinia play an important role as a spice in some regions of Mexico. In fact, the aril of the fruits is used to enhance flavor in tortillas, and their leaves are used as wrapping for different kinds of food [14,15]. Our studies have shown that rhizomes and leaf extracts of $R$. alpinia inhibit the toxic and lethal effects of the poisonous venom of the Bothrops atrox and B. asper [16-18]. We also found that the main bioactive component of the dichloromethane extract is the flavanone pinostrobin that has the inhibitory capacity of the coagulant, proteolytic, hemolytic and hemorrhagic effects of B. atrox- B. asper poison [18]. Moreover, some isolated $R$. alpinia pure compounds were evaluated through the Siegmund test to assess activity on the peripheral nervous system [18] in animal models.

The objective of this research is the evaluation of the analgesic activity of two $R$. alpinia essential oils obtained from leaves of wild and micropropagated plant samples. In addition, a comparative chemical analysis of the essential oils was carried out by gas-chromatography massspectroscopy (GC-MS).

\section{Materials and Methods}

\subsection{Plant Material}

The leaves of $R$. alpinia (Rottb.) Maas obtained from wild flora were collected in Dantas village, located in the municipality of San Rafael, latitude $06^{\circ} 118^{\prime} \mathrm{N} 75^{\circ} 101^{\prime} \mathrm{W}$ (Antioquia-Colombia). It was identified and authenticated at the Herbarium of the University of Antioquia (HUA) and assigned a voucher number 176395 .

In vitro culture of $R$. alpinia was obtained from three hundred and sixty (360) seedlings collected in the village of Titumate, Unguía, (5 m.a.s.1, Chocó, Colombia). It germinated in a room at the biological station of the University of Antioquia, and was identified in the HUA. The seedlings were washed once with iodine soap and running water, disinfected through exposure to sodium hypochlorite $(\mathrm{NaClO})(2 \%, 25 \mathrm{~min})$, then transferred aseptically to culture vials with a nutrient medium previously sterilized by moist heat $\left(121^{\circ} \mathrm{C}\right)$. The environment is made up of basic salts of Murashige and Skoog $[19,20], \mathrm{pH}=5.8$, sucrose $(30 \mathrm{~g} / \mathrm{L})$ and agar $(7 \mathrm{~g} / \mathrm{L})$. Once established, the micropropagated seedlings were subjected to subculture every four weeks, kept at a controlled temperature $\left(25{ }^{\circ} \mathrm{C}\right)$ and photoperiod of 1 day ( $16 \mathrm{~h}$ of light, $50 \mathrm{~mol} \mathrm{~m}^{-2} \mathrm{~s}^{-1}$ ).

Both the wild plant material and micropropagated plants were dried at $38^{\circ} \mathrm{C}$ for $4 \mathrm{~h}$ and then pulverized in a mill (Covenant Electro motor RPM $50 \mathrm{~Hz}$ ) after which they were deposited and stored in airtight containers in a cool, dry place and protected until usage.

\subsection{Extraction of Essential Oils}

To obtain the essential oils of wild $R$. alpinia (EORaw) and in vitro culture (EORaiv), the following methodology was carried out: the plant materials underwent hydrodistillation in a Clevenger-type device, with recirculation, refrigerated water and temperature control until depleting extraction ( $2 \mathrm{~h}$, boiling temperature); $180 \mathrm{~g}$ of wild plant material and $90 \mathrm{~g}$ of plant material of culture in vitro were used, obtaining yields of $0.07 \%$ and $0.04 \%$ respectively; the collected essential oils were dried by adding sodium anhydrous sulfate, packed in glass bottles and stored under refrigeration $\left(4{ }^{\circ} \mathrm{C}\right)$; the vials were protected from light and humidity until usage. 


\subsection{Experimental Animals}

Swiss mice (males and females) with a weight of $23 \pm 1 \mathrm{~g}$ were used, supplied by the animal facility of the University of Antioquia. The animals were previously housed at room temperature (22 \pm $1{ }^{\circ} \mathrm{C}$ ) relative humidity of $50-60 \%$ and $12 \mathrm{~h}$ of light-dark cycles with food and free access to water. Two days prior to the experiment, the mice were allowed to adapt to the environment. The animals were treated under the standards of care for experimental animals of the Canadian Council for the Protection of Animals, with the endorsement of the Ethics Committee for the Experimentation with Animals of the University of Antioquia, Act No. 65/2010, and in accordance with law 84 of 1989 of the Congress of Colombia.

\subsection{Analgesic Activity}

In order to evaluate the analgesic activity, the following method was developed [21]: mice were randomly separated into seven groups (4 animals per group), then administered orally with the negative control group receiving vehicle (Tween $80,5 \%$ ) and the positive control group receiving ibuprofen $75 \mathrm{mg} / \mathrm{kg}$ (PBS, pH 7.2 buffer solution). The five remaining groups received doses of essential oil of wild and in vitro culture R. alpinia, of 50,100 and $200 \mathrm{mg} / \mathrm{kg}$ for EORaw, and 50 and $100 \mathrm{mg} / \mathrm{kg}$ for EORaiv. After 30 minutes, all of the mice received an intraperitoneal injection of phenylquinone $(4 \mathrm{mg} / \mathrm{kg}) .5 \mathrm{~min}$ later, the mice were placed in individual boxes for observation and the number of back-abdominal stretches were determined as evidence of visceral pain for a period of $15 \mathrm{~min}$. Mice with a decrease in the number of twists were protected by the respective dose of essential oil. The percentage of inhibition of pain was calculated by the formula:

$\% \mathrm{I}=\mathrm{Gc}-\mathrm{Gt} / \mathrm{Gc} * 100$

Where $\mathrm{Gc}$ is the average of the negative control group stretches and Gt is an average of stretches of the treated group.

\subsection{Statistical Analysis}

The results were expressed as the values of the mean \pm SEM of measurements in each group. A comparison of the groups was performed using an analysis of variance (ANOVA) one-way with Dunnett's test post hoc. A p-value $p<0,05$ criterion of statistical significance was applied. The GraphPad Prism ${ }^{\circledR}$ software for statistical analysis was used.

\subsection{GC/MS Analysis}

The chemical analysis of the essential oils was performed by gas chromatography-mass spectrophotometry (GC-MS) on a Varian gas chromatograph 3800® coupled with mass spectrometer Varian Saturn ion trap 2000®. The electron impact ionization technique $(70 \mathrm{eV})$ and selected mass range $40-350 \mathrm{~m} / \mathrm{z}$ were used. Carrier gas was helium at rate of $1 \mathrm{~mL} / \mathrm{min}$. The samples were run in two different columns: 1. Capillary column Carbowax $20 \mathrm{M} \circledR(30 \mathrm{~m}$ x $0.25 \mathrm{~mm}$ i.d. x $0,25 \mu \mathrm{m}$ film), program of temperature: $45^{\circ} \mathrm{C}$ for $3 \mathrm{~min}, 45-240^{\circ} \mathrm{C}$ to $5^{\circ} \mathrm{C} / \mathrm{min}$, temperature of the injector $230^{\circ} \mathrm{C}$, mode of injection $1 \mu \mathrm{L}$ to split (1:15). 2. Capillary column DB - $5 \mathrm{~ms}{ }^{\circledR}(50 \mathrm{~m} \times 0.20 \mathrm{~mm}$ i.d.x $0.33 \mu \mathrm{m}$ film), program of temperature: $45^{\circ} \mathrm{C}$ for $3 \mathrm{~min}, 45-280{ }^{\circ} \mathrm{C}$ to $5{ }^{\circ} \mathrm{C} / \mathrm{min}, 280{ }^{\circ} \mathrm{C}$ for $15 \mathrm{~min}$, temperature of the injector $240{ }^{\circ} \mathrm{C}$, mode of injection $1 \mu \mathrm{L}$ to split (1:15). Identification of the components was made by comparing their mass spectra with those stored in the libraries of AMDIS/NIST ${ }^{\circledR}$, and taking as reference the chemical characterization of essential oil of $R$. alpinia by Maia et al [22]. 


\section{Results and Discussion}

\subsection{Analgesic activity}

Mice treated with EORaw and EORaiv in doses of 50,100, $200 \mathrm{mg} / \mathrm{kg}$, and 50 and $100 \mathrm{mg} / \mathrm{kg}$ respectively, experienced a significant reduction in stretching, compared with the negative control group, with higher doses having greater effect. The highest percentage of inhibition of pain presented itself in the EORaw $200 \mathrm{mg} / \mathrm{kg}(92.0 \%)$. Detailed information on the effect of essential oils on phenylquinone-induced stretches is shown in table 1.

Table 1. Effect of EORaw and EORaiv (essential oils of R. alpinia) on pain.

\begin{tabular}{llc}
\hline Group & $\begin{array}{c}\text { No. Stretching } \\
(\overline{\mathbf{X}} \pm \text { SEM) }\end{array}$ & Inhibition \% of pain \\
\hline Ibuprofen $75 \mathrm{mg} / \mathrm{kg}$ & $5.00 \pm 1.15^{* * *}$ & 84.0 \\
EORaw $50 \mathrm{mg} / \mathrm{kg}$ & $6.50 \pm 2.63^{* * *}$ & 79.2 \\
EORaw $100 \mathrm{mg} / \mathrm{kg}$ & $3.50 \pm 0.87^{* * *}$ & 88.5 \\
EORaw $200 \mathrm{mg} / \mathrm{kg}$ & $2.50 \pm 0.29^{* * *}$ & 92.0 \\
EORaiv $50 \mathrm{mg} / \mathrm{kg}$ & $9.50 \pm 0.29^{* * *}$ & 69.6 \\
EORaiv $100 \mathrm{mg} / \mathrm{kg}$ & $6.50 \pm 1.44^{* * *}$ & 79.2 \\
Control $(-)$ & $31.25 \pm 0.95$ & --- \\
\hline
\end{tabular}

An analysis of one-way ANOVA and Dunnett's test was used as a post-hoc test. The results of each group $(n=4)$ are expressed as values of $\overline{\mathrm{x}} \pm \mathrm{SEM}$. Significant differences were considered when ${ }^{*} \mathrm{p}<0.05,{ }^{*} \mathrm{p} \leq 0.001$, $* * * \mathrm{p} \leq 0.0001$ were compared with the negative control.

Table 1 revealed that the essential oils obtained from wild flora are more potent than the in vitro cultured. For example, with a $100 \mathrm{mg} / \mathrm{kg}$ dose, the essential oil sample from wild flora showed an inhibition percentage of $88.5 \%$, greater than the essential oil of cultivation in vitro, which was $79.2 \%$, with comparable data of the positive control ibuprofen at $75 \mathrm{mg} / \mathrm{kg}$ dose $84.0 \%$.

We showed that oral administration of both essential oils of $R$. alpinia wild and micropropagated at doses of 50, 100 and $200 \mathrm{mg} / \mathrm{kg}$ produced significant dose-dependent inhibition against the chemical induced nociception test model (Table 1). Terpenes, the main constituents of $R$. alpinia essential oils showed interesting results that confirm its analgesic and anti-inflammatory activity [23]. Fonseca et al, showed that nerolidol has effects in chemical nociception models and demonstrated that the analgesic activity is mediated by the peripheral nervous system and not by the central nervous system, conducting experiments for both cases and that activity is related to the GABAergic system [24]. In addition, according to Chavan [25], the caryophyllene oxide, which is the second most important component in EORaiv, possesses some antinociceptive properties that have demonstrated centrally and peripherally mediated analgesia by caryophyllene oxide. Based on the above, it is possible to suggest that the higher percentage of trans-Nerolidol and caryophyllene/caryophyllene oxide can be considered as responsible for the antinociceptive activity of $R$. alpinia essential oils.

Phenylquinone induced writhing test in mice is used to screen and study compounds for peripherally mediated analgesic activity. Peritoneal administration of phenylquinone induces endogenous pain mediators such as prostaglandins, histamine, serotonin (5-HT) and bradykinin that sensitize pain nerve endings. The released prostaglandins, mainly prostacyclin (PGI2) and to lesser extent PGE2 and PGF2 $\alpha$ have been held responsible for pain sensation. Our results highlight the important role of analgesic activity with a mechanism of action that could be similar to ibuprofen, which prevents the synthesis of prostaglandins through inhibition of the enzyme cyclooxygenase 1 and 2 (COX1, COX2). Consequently, this brings about a decrease in the formation of precursors of prostaglandins and thromboxanes, resulting in an obvious pain decrease. We suggest that the $R$. alpinia essential oils carry a significant peripherally mediated analgesic [26,27]. 


\subsection{Chemical analysis of the Essential Oils}

The quantitative analysis of the chemical profiles of essential oils from $R$. alpinia is shown in Table 2. The table includes a class of secondary metabolites (constituent), retention index, area in both essential oils from wild and in vitro grown $R$. alpinia and the percentage of the components identified. Fifteen compounds were identified from in vitro plants and twelve from the essential oil of the wild plants, which consist primarily of monoterpenes and sesquiterpenes. The results are shown in table 2 .

Table 2. Chemical composition and retention indices of the essential oils of R. alpinia.

\begin{tabular}{|c|c|c|c|c|}
\hline Constituent & RI Lit. $^{a}$ & $\mathbf{R I}^{\mathbf{d}}$ & EORaw (\%) & $\begin{array}{c}\begin{array}{c}\text { EORaiv } \\
(\%)\end{array} \\
\end{array}$ \\
\hline$\alpha$-Pinene & $921-944^{a}$ & 942 & 31.4 & 1.0 \\
\hline$\beta$-Pinene & $964-988^{a}$ & 989 & 4.5 & 2.9 \\
\hline$o$-Cymene & $1001-1076^{a}$ & 1032 & 0.1 & 0.5 \\
\hline Limonene & $1019-1039^{a}$ & 1038 & 2.6 & 0.3 \\
\hline$\beta$-phellandrene & $1011-1043^{a}$ & 1041 & nd & 3.0 \\
\hline Pinocarvone $^{1}$ & $1144-1167^{\mathrm{a}}$ & 1177 & nd & 2.6 \\
\hline Dihydroedulan II* & $1278^{\mathrm{b}}$ & 1258 & 0.3 & 1.8 \\
\hline$\beta$-Elemene* & $1395^{c}$ & 1311 & nd & 3.7 \\
\hline$\beta$-Caryophyllene & $1392-1430^{a}$ & 1357 & 7.8 & 1.1 \\
\hline$\beta$-Humulene & $1436-1456^{\mathrm{a}}$ & 1402 & 2.7 & 8.9 \\
\hline$\delta$-Cadinene & $1498-1531^{\mathrm{a}}$ & 1485 & 1.2 & nd \\
\hline trans-Nerolidol & $1539-1570^{a}$ & 1496 & 40.9 & 32.0 \\
\hline Caryophyllene oxide & $1563-1595^{\mathrm{a}}$ & 1525 & 2.5 & 15.9 \\
\hline Farnesol* & $1678-1700^{\mathrm{a}}$ & 1693 & 1.7 & 12.4 \\
\hline Alloaromadendrene ${ }^{2}$ & $1624-1668^{\mathrm{a}}$ & 1658 & nd & 0.7 \\
\hline Valencene ${ }^{* 2}$ & $1668-1761^{\mathrm{a}}$ & 1715 & 4.3 & 13.4 \\
\hline Total & & & 100.0 & 100.0 \\
\hline
\end{tabular}

RI Literature a) [28] b) [29] c) [30]. b and c are given in average. d) Retention Index determined with reference to a DB5ms ${ }^{\circledR}$ column. ${ }^{1}$ Compound identified only in column DB - 5ms ${ }^{\circledR} .{ }^{2}$ Compounds identified only in column Carbowax 20M®. *Compounds reported for the first time for $R$. alpinia. nd: not detected.

Essential oils are a group of secondary metabolites that currently have a productive significance [31]. Many of them are valued for their qualities as potential medicinal products [32] and cosmetics [33]. In this study, the use of two chromatographic columns was fundamental, one with polar characteristics (Carbowax 20M ${ }^{\circledR}$ ), and the other with apolar characteristics (DB - 5ms $\left.{ }^{\circledR}\right)$, since they complemented the research well, generating confidence in the results obtained. A hydrodistillation method was employed for the extraction of volatiles from vegetal material (micropropagated and wild), using short times $\left(90-180 \mathrm{~m}\right.$ ), controlled temperature (water recirculation at $4{ }^{\circ} \mathrm{C}$ ) and scarce loss of compounds that grant product aroma and biofunctionality. 
Table 2 shows that the essential oil of wild samples contains greater wealth from the chemical point of view than the essential oil of in vitro culture revealing substantial differences in the chemical composition. Although, the main component in both essential oils is trans-nerolidol, its percentage in EORaw $(40.9 \%)$ is almost $9 \%$ more than in the oil of the micropropagated plant (32\%) (Table 2). In addition, the second main component found in wild $R$. alpinia is the $\alpha$-pinene $(31.4 \%)$ while in the micropropagated plant this compound only represents $1 \%$. On the other hand, for the micropropagated plant, we identified caryophyllene oxide as the second most abundant component (15.9\%), while in the wild plant this compound only represents $2.5 \%$ of its composition. In general, the analysis of the $R$. alpinia essential oils derived from the identification of sixteen compounds. Four of them were not reported before for this botanical species (dihydroedulan II, $\beta$-elemene, farnesyl methyl ester and valencene). Our results are in accordance with previous reports for Renealmia genus essential oils, where terpenes are the main components $[34,35]$. The difference in the composition can be attributed to the development conditions of the plants. Abiotic factors such as humidity, temperature, $\mathrm{pH}$ and soil nutrients create environmental stress on the plant and this is likely to result in production of additional secondary metabolites. Besides, the plants exposed to abiotic stimulus with which they have coevolved, also promote the development of different biosynthetic pathways through which a large variety of secondary metabolites are biosynthesized [36, 37].

In summary, our results contribute to the knowledge on the use of this medicinal plant. The findings demonstrate that the essential oil of $R$. alpinia presents analgesic activity with significant results on an in vivo model. This is the first time that the $R$. alpinia essential oils were studied in relation to their in vivo antinociceptive activity. Future studies are underway to identify its mechanism of analgesic action. These results suggested the potential feasibility of $R$. alpinia as a food ingredient, as well as their possible applications in the pharmaceutical industry.

\section{Acknowledgments}

The authors would like to extend their thanks to the Center of Research of the Faculty of Pharmaceutical and Food Sciences at the University of Antioquia for the financial support. Thanks also to the Sustainability Program 2016-2017 and to the Ophidism/Scorpionism Program of the University of Antioquia as well as the Group of Research on Bioactive Substances, and the Institute of Chemistry (UdeA).

\section{ORCID}

Isabel Gómez-Betancur: 0000-0003-2550-892X

Dora Benjumea: 0000-0003-4827-9971

Juan E. Gómez: 0000-0001-8527-2985

Natalia Mejia: $0000-0001-5134-6587$

Juan F. León: 0000-0002-5064-2381

\section{References}

[1] Dueñas. M, Ojeda. B, Salazar. A, Mico. JA and Failde (2016). I. A review of chronic pain impact on patients, their social environment and the health care system, J. Pain. Res. 9, 457-467.

[2] L. Guerrero and L. Gómez (2014). Prevalencia del Dolor Crónico en Colombia, VIII Estudio Nacional de Dolor. Firma encuestadora: Datexco.

[3] World Health Organization (1999). WHO monographs on selected medicinal plants. Volumen 1. Ginebra: World Health Organization; 289p.

[4] J. Calixto (2005). Twenty-five years of research on medicinal plants in Latin America: a personal view, J. Ethnopharmacol. 100, 131-134.

[5] J. Calixto (2000). Efficacy safety quality control marketing and regulatory guidelines for herbal medicines (phytotherapeutic agents), Bras. J. Med. Biol. Res. 33, 179-189.

[6] J. Wirth, J. Hudgins and J. Paice (2005). Use of herbal therapies to relieve pain: A review of efficacy and adverse effects, Pain. Manag. Nurs. 6, 145-167. 
[7] J. Steinmeyer (2000). Pharmacological basis for the therapy of pain and inflammation with nonsteroidal anti-inflammatory drugs, Arthritis Res. 2, 379-385.

[8] P. Swati and S. Dibyaiyoti (2013). Analgesic activity of methanol extract of Alpinia conchigera Griff by acetic acid induced Writhing method, Asian. J. Res. Pharm. Sci. 2, 62-65.

[9] A. Vendruscolo, I. Takaki, L. Bersani-Amado, J. Dantas and C. Bersani-Amado (2006). Antiinflammatory and antinociceptive activities of Zingiber officinale Roscoe essential oil in experimental animal models, Indian. J. Pharmacol. 38, 58-59.

[10] M. Sulaiman, E. Perimal, Z. Zacaria, F. Mokhtar, M. Akhtar, N. Lajis and D. Israf (2009). Preliminary analysis of the antinociceptive activity of zerumbone, Fitoterapia 80, 230-232.

[11] R. Otero, R. Fonnegra, S. Jiménez, V. Núñez, N. Evans, S. Alzate, M. García, M. Saldarriaga, G. del Valle G, R. Osorio, A. Díaz, R. Valderrama, A. Duque and H. Vélez (2000a). Snakebites and ethnobotany in the northwest region of Colombia Part I: Traditional use of plants, $J$. Ethnopharmacol. 71, 493-504.

[12] M. Coelho (2009). Medicinal knowledge and plant utilization in an Amazonian coastal community of Marudá, Pará State (Brazil), J. Ethnopharmacol. 126, 159-175.

[13] Coe G (2008). Rama midwifery in eastern Nicaragua, J. Ethnopharmacol. 117, 136-157.

[14] J. Macia (2003). Renealmia alpinia (ROTTB) Maas (Zingiberaceae): Planta comestible de la sierra Norte de puebla (México), Anales Jard. Bot. Madrid 60 183-187.

[15] M.L. Luna Guevara, J.J. Luna Guevara, N.V. Garcia Lobato, P. Hernandez Carranza and C.E. Ochoa Velasco (2016). Corn tortillas enriched with the fruit pulp of xkijit [Renealmia alpinia (rottb.) maas]. Mx Patent 2016-2016002193, filled February 18, 2016, issued May 5, 2016

[16] R. Otero, V. Núñez, S. Jiménez, R. Fonnegra, R. Osorio, M. García and A. Díaz (2000). Snakebites and ethnobotany in the northwest region of Colombia Part II: Neutralization of lethal and enzymatic effects of Bothrops atrox venom, J. Ethnopharmacol. 71, 505-511.

[17] A. Patiño, J. Lopez, M. Aristizabal, C. Quintana and D. Benjumea (2012). Efecto inhibitorio de extractos de Renealmia alpinia Rottb. Maas (Zingiberaceae) sobre el veneno de Bothrops asper (mapaná), Biomédica 32, 365-374.

[18] I. Gómez-Betancur, D. Benjumea, A. Patiño, N. Jiménez and E. Osorio (2014). Inhibition of the toxic effects of Bothrops asper venom by pinostrobin, a flavanone isolated from Renealmia lpinia (Rottb.) MAAS, J. Ethnopharmacol. 155, 1609-1615.

[19] T. Murashige and F. Skoog (1962). A revised medium for rapid growth and bioassays with tobacco tissue cultures, Physiol. Plant. 15, 473-497.

[20] A. Abdelnour and J.V. Escalant (1994). Conceptos básicos del cultivo de tejidos vegetales. CATIE (Centro agronómico tropical de investigación y enseñanza). Costa Rica.

[21] E. Siegmund, R. Cadmus and G. Lu (1957). A method for evaluating both non-narcotic and narcotic analgesics. Proc. Soc. Exp. Biol. Med. 95, 729-731.

[22] J. Maia, E. Andrade, L. Carreira and M. da Silva (2007). Essential Oil Composition of Renealmia alpinia (Rottb.) Maas., J. Essent. Oils. Bear. Pl. 10, 10-14.

[23] V. Rao, A. Menezes and G. Viana (1990). Effect of myrcene on nociception in mice, Int. J. Pharm. Pharm. Sci. 42, 877-878.

[24] D. Fonseca, P. Salgado, F. de Carvalho, M. Salvadori, A. Penha, L. Clovis Borges, M. Piuvezam, L. de Morais Pordeus, D. Sousa and R. Almeida (2016). Nerolidol exhibits antinociceptive and anti-inflammatory activity: involvement of the GABAergic system and proinflammatory cytokines, Fundam. Clin. Pharmacol. 30, 14-22.

[25] M.J. Chavan, P.S. Wakte and D.B. Shinde (2010). Analgesic and Anti-inflammatory activity of Caryophyllene oxide from Annona squamosa, Phytomedicine. 17, 149-151.

[26] A.R. Ronaldo, L.V. Mariana, M.T. Sara, B.P. Adriana, P. Steve, S.H. Ferreira and Q.C. Fernando (2000). Involvement of resident macrophages and mast cells in the writhing nociceptive response induced by zymosan and acetic acid in mice, Eur. J. Pharmacol. 387, 111-118.

[27] R. Derardt, S. Jougney, F. Delevalcee and M. Falhout (1980). Release of prostaglandins E and F in an algogenic reaction and its inhibition, Eur. J. Pharmacol. 51, 17-24.

[28] V.L. Babushok, P.J. Linstrom and I.G. Zenkevich (2011). Retention indices for reported compounds of plant essential oils, J. Phys. Chem. Ref. Data 40, 043101

[29] C.P. Duschatzky, N.V. Almeida, M. Possetto, F. Michis, E. Scappini, M.P. de Lampasona and C. Schuff (2007). Essential oil composition of Heterothalamus alienus (Spreng.) Kuntze (Romerillo) from Argentina. Effect of harvesting period on the essential oil composition, Flavour Frag. J. 22, 39-41.

[30] I. Duarte, C.A. Lima, N. Ré-Poppi, A. Mestriner, M. do Carmo, N.K. Honda and R. Gomes (2009). Gas Chromatography-Mass Spectrometry (GC-MS) and evaluation of antioxidant and antimicrobial 
activities of essential oil of Campomanesia adamantium (Cambess.) O. Berg (Guavira), Braz. J. Pharm. Sci. 45, 767-776.

[31] E. Schmidt (2015). Handbook of essential oils: science, technology, and applications. Production of Essential Oils. CRC Press.

[32] P. Noriega (2009). Extracción, química, actividad biológica, control de calidad y potencial económico de los aceites esenciales, La Granja. 10, 3-15.

[33] A. Muñoz-Acevedo, E.A. Torres, R.G. Gutiérrez, S.B. Cotes, M. Cervantes Díaz and G. TafurtGarcía (2015). Some Latin American Plants Promising for the Cosmetic, Perfume and Flavor Industries. Therapeutic Medicinal Plants: From Lab to the Market. CRC press.

[34] A.I.R. Luz, M.G.B. Zoghbi, L.S. Ramos, J.G.S. Maia and M.L. Silva (1984). Essential oils of some Amazonian Zingiberaceae, genera Alpinia and Rengalmia. Departamento de Produtos Naturais, Instituto Nasional de Pesquisa da Amazonia (INPA), Conselho Nasional de Desenuoluimento Czentifio e Ternoldgiro (CNPq), 6900, Manaus, Amazonas, Brazil.

[35] P. Noriega, E. Paredes, T. Mosquera, E. Díaz, A. Lueckhoff, J. Basantes and A. Trujillo (2016). Chemical Composition antimicrobial and free radical scavenging activity of essential oil from leaves of Renealmia thyrsoidea (Ruiz \& Pav.) Poepp. \& Endl, J. Med. Plants. Res. 10, 553-558.

[36] N. Dudareva and E. Pichersky (2000). Biochemical and molecular genetics aspects of floral scents, Plant. Physiology. 122, 627-633

[37] I. Gómez-Betancur, N. Cortés, D. Benjumea, E. Osorio, F. León and S. Cutler (2015). Antinociceptive activity of extracts and secondary metabolites from wild growing and micropropagated plants of Renealmia alpinia, J. Ethnopharmacol. 165, 191-197.

\section{A C G \\ publications \\ (C) 2018 ACG Publications}

